\title{
INSURANCE AND INDEMNITY PROBLEMS IN OFFSHORE DRILLING OPERATIONS
}

\author{
W. J. HOPE-ROSS*
}

\begin{abstract}
This paper examines marine insurance and indemnity as it relates to offshore drilling. It looks at obvious natural risks which are difficult to insure against, and then discusses Hull insurance, which is the insurance on the "hull and machinery" of a seagoing vessel; Protection and Indemnity insurance, which is the "public liability" coverage for shipowners; Tower's Liability insurance which is commonly overlooked by small operators, but which is essential to protect against loss of the drilling barge when it is under tow; and Excess Liability or "Umbrella" insurance which is additional insurance monies, or secondary insurance coverage, for public liability. In discussing indemnity provisions, the author suggests that present indemnity clauses are not entirely satisfactory and that a better approach may be an agreed proportioning of the risk in the individual contracts. Workmen's Compensation has a jurisdictional problem in Canadian waters; both as between the federal and provincial governments and as between the United States and Canada. Added employer's liability coverage is the recommendation.
\end{abstract}

\section{INTRODUCTION}

The risks of drilling a well in twenty fathoms of tempestuous water are obviously far more complex than those of drilling a well on solid ground in the lea of the Alberta foothills. Wild wells and blowouts are more ominous at sea. Seepage and pollution is potentially more of a problem. If the well is off Canada's East Coast, workmen's compensation may be a problem. Icebergs create a danger unknown to land-lubber roughnecks. And, because the whole operation takes place at sea, it is subject to marine law. Most Canadian oil and gas lawyers know little marine law, because most of the significant petroleum finds until recently were on the landlocked prairies.

It will be the object of this paper then, to examine what can be done to insure against these peculiar physical risks and, secondly, to examine the marine insurance law to try to shed some light on the insurance and indemnity requirements for oceanic drilling operations with respect to the rig itself and personnel employed upon it and in relation to it.

\section{NATURAL RISKS}

The problems seem obvious. There is a well being punched in the floor of the sea. If that well goes wild or blows out or craters, the potential result will be the loss of thousands of fish and a slick fed by thousands of pounds of reservoir pressure and borne about by shifting underwater currents as well as the usual surface swell and wave and tidal action. On the other hand, if an iceberg the size of a ten-storey building begins drifting toward a drilling rig there is an obvious risk of total loss of rig and crew.

The two preceding natural risks have a mutual problem. They are virtually unable to be insured against. The Torrey Canyon scare, coupled with the problem of determining responsibility when there may be several joint owner-operators as well as the drilling contractor, and in-

- Barrister and Solicitor, Hudson's Bay Oil and Gas Co., Ltd., Calgary, Alberta. 
numerable sub-contractors, makes the underwriters' position understandable. It would be unlikely that much more than one million dollars worth of pollution insurance could presently be obtained in the world market. That would scarcely pay for the nervous shock to the bird watchers on Peggy's Cove. However, iceberg coverage can be obtained if a company is willing to pay the price, but the costs are so prohibitive that it is impractical to carry coverage.

The result is that operators become self-insured for the excess above whatever insurance can be obtained. To most companies, (indeed, to a lot of joint ventures), the expenses of a major spill might mean bankruptcy. However, the ecologists may have created a fear which unduly raises insurance premiums and makes obtaining insurance difficult or impossible. Oil on the sea itself does little damage, except to the birds which happen to land in it. Light oils, such as diesel oil, evaporate quickly. Even with crude oil, the light ends evaporate and the heavier residues are destroyed by photosynthesis and do eventually sink to the ocean floor (where lower forms of life thrive upon its high protein content) and, because oil rises to the surface of water, it can be contained relatively easily by booms. So long as it is at sea, it can be cleaned up relatively easily. The result is that companies now establish their own emergency pollution control stations so that a leak can be surrounded by booms in a matter of hours following its occurrence. This may be the best insurance available. Smaller operators would have to negotiate a lease or share agreement with a major operator who has the necessary equipment in the area to make this protection practical for them.

The pollution problem discussed above is, of course, a matter of third party liability. What causes the pollution-blowouts, cratering, or wild wells-does cause real loss to the operator and the rig and, as on land, these things can be insured against to some extent. That type of insurance shall be touched upon later in this paper.

The other natural risk raised was with respect to ice conditions. In Eastern and Arctic Canadian waters, marine adventures are subject to additional premiums during certain seasons of the year because of the increased risk of ice damage. The problem is not peculiar to drilling operations, of course. Ship owners have for years argued with the underwriters about the amounts of additional premiums demanded, the periods during which the additional premiums should be or are payable, and the areas of the sea which should be subject to the additional premiums.

A portion of a brief submitted by Sydney Steel Corporation to the Canadian Transport Commission's inquiry into the coasting trade of Canada ${ }^{1}$ illustrates the point: ${ }^{2}$

Currently, substantial additional premiums are required for breach of BNA warranty limits. Use of Canadian registered vessels carry relatively higher premium costs since these premiums are based on the valuation of these ships with their attendant higher construction costs. Last season for a period of about 6 weeks from December 23 to January 29 this premium cost amounted to 24 cents per ton on the 351,210 tons carried in excess of our normal freighting cost. This has resulted in an increase in the cost of our freighting of about $32 \%$ during this period. Indeed, for voyages performed in the period February 1 to 15 the per voyage cost of additional premiums for cargoes of 30,500 net tons would amount to $\$ 13,500$ or 44 cents per ton.

\footnotetext{
1 Darling, Report of Inquiry on The Coasting Trade of Canada and Related Marine Activity (1970).

2 Id. at 141 .
} 
The Hull Underwriters in assessing the additional premiums for the period indicated do so on the assumption that the so called BNA area including the Gulf and St. Lawrence River are subject to abnormal hazards the degree of which we feel cannot be supported. With but few exceptions over the last number of years the month of January in particular has been extremely favourable for trading in the Gulf of St. Lawrence and in our opinion should not be subjected to these heavy penalties. Apparently, not sufficient allowance is being made for the extensive aids to navigation including ice breaker and air patrol service being supplied particularly in the Gulf.

It is not necessary to belabour the point. A substantial amount of marine insurance for the world is done through Lloyd's of England. Some concession in the additional premium rate has been introduced for icestrengthened vessels. Lloyd's Class 1 for ice reduces the additional premium by fifty percent; twenty-five percent for Lloyd's Class 2; and twelve and one-half percent for Lloyd's Class 3. Still, these reductions do not seem that great in light of the improvements in navigational equipment, experience, ice surveying, and ice-strengthening of equipment.

When you relate this to a stationary drilling unit, or a barge anchored in place and equipped for the taking of production, it will be understood that the best insurance is a drilling program during the months of April to October and the best marine ice surveyor a company can hire. It is no wonder that there has been experimentation with the diversion of icebergs by tug boat and blasting. Drilling contracts provide for standby rates in the event of storms and there may be a tendency to provide for ice conditions in a similar fashion as the drillers become more familiar with the working conditions in icy waters.

There are other natural risks, of course, not mentioned in this paper. Storms wreak destruction which may not be fully considered when letting a drilling contract. The type of rig used, such as a jack-up rig as opposed to a drilling barge, will result in a lowering of premiums for decreased storm risk.

\section{MARINE INSURANCE}

It is in the day-to-day workings of the drilling operations where man controls his destiny and that is the area of activity-risk in which insurance and indemnity play an important role.

There are three forms of marine insurance which are applicable to most phases of an offshore drilling operation. These are Hull, Protection and Indemnity, and Tower's Liability.

\section{Hull Insurance}

Hull insurance means the insurance on the vessel and, in the case of a vessel engaged in a special trade such as oil well drilling, includes the ordinary fittings requisite for the trade: i.e. the derrick. Hull insurance protects against the loss of the vessel. It covers the costs of attempting to refloat a sunken barge, even if the attempt fails. This means that the assured may recover more than the face value of the policy, which is based upon the value of the vessel. If it is totally lost, the assured may be reimbursed for it at the policy's face value, plus the costs of attempted recovery. Hull insurance is also collision insurance. In that respect it is akin to the "property damage" aspect of automobile insurance.

All work boats and supply boats will, of course, carry Hull insurance, although to varying degrees. Because these boats are often operated by 
independent contractors, it is necessary to insist upon receiving copies of their insurance certificates. This requirement extends to their P \& I and Tower's Liability; probably to an even greater extent.

\title{
2. The Conflicts Problem
}

The Hull policy for the drilling rig is usually in one of two standard forms; either in the London Standard All Risks Drilling Form or in the American Institute of Marine Underwriters' Form. Both forms have world-wide acceptance.

Before discussing the form of the policies, it might be worthwhile to at least raise the conflicts problem presented by the use of these forms. There is usually no problem when the law intended is specified in the contract. When the contract is silent, courts try to determine the intent of the parties and have applied either the law of the place of performance; the law of the place of making of the contract; or the law of the flag. There may be liability under American law if an act were tortious under the lex loci delictus, whereas in England, the act must be tortious under English law as well. This becomes extremely important if, for example, there is a collision in Canadian territorial waters between an American supply boat and an American drilling barge. ${ }^{3}$

There are other conflicts problems, but they are not directly in line with the wide scope of this paper, so having raised this as an area of which to beware and recognizing that it can be solved simply by specifying the law applicable, ${ }^{4}$ we return to the discussion of the Hull policy form as it applies to the drilling rig.

The typical drilling contract calls for Hull insurance to the full value of the rig, perhaps with a deductible of $\$ 25,000$ to $\$ 50,000$. The contract stipulates: "This insurance shall include full collision liability with the Sistership Clause unamended." The "Sistership Clause" is designed to state the legal position where two ships belonging to the same owner collide and reads as follows: ${ }^{5}$

\begin{abstract}
Should the Vessel hereby insured come into collision with or receive salvage services from another vessel belonging wholly or in part to the same Owners or under the same management, the Assured shall have the same rights under this Policy as they would have were the other vessel entirely the property of Owners not interested in the Vessel hereby insured; but in such cases the liability for the collision or the amount payable for the services rendered shall be referred to a sole arbitrator to be agreed upon between the Underwriters and the Assured.
\end{abstract}

Without this clause, the assured could not proceed against the owner of the ship which was in collision with the drilling barge, because he would have to sue the shipowner as defendant in the name of the same owner as plaintiff. There are really not many problems with Hull insurance. Protection and Indemnity insurance is "catch-all" insurance and because of the enormous number of risks which should be covered it must be examined carefully.

\footnotetext{
3 See e.g. Interlake S.S. Co. v. American S.S. Co. (1950) Am. Mar. Cas. 1678 (S.D.N.Y.), where the law of the flag (American law) was applied; although it is interesting to note that the action was tried in United States courts.

- When a contract's validity is in issue and the contract has no substantial relation to the jurisdiction selected, courts will reject choice of law clauses. They do so on grounds of public policy.

In marine insurance, there is a conflict of laws as a result of the varying requirements with respect to insurable interest. Wagers are not allowed in either jurisdiction, but P.P.I. stipulations ("policy is proof of interest") are acceptable in the United States, whereas the Marine Insurance Act, 1906, 6 Edw. VII, c. 41 voids all policies which waive proof of interest.

S Ivamy, Marine Insurance 212 (1969).
} 


\section{Protection and Indemnity}

$P$ \& I insurance covers the loss of life and personal injury to the people aboard the insured vessel and also on the vessel collided with. It is, if you like, "public liability" coverage. The principal risks insured against under $\mathrm{P} \& \mathrm{I}$, in addition to loss of life or physical injury or illness, are costs associated therewith such as hospital, medical, and funeral expenses, crew substitution expenses, loss of personal effects of the seamen, additional collision coverage for losses not covered by Hull insurance, damage to docks, peers, buoys and the like, removal of wrecks, quarantine expenses, fines for failure to maintain safe working conditions, and legal expenses.

Some of the above expenses are required to be paid under statutory obligation in some jurisdictions or under union agreements and that is why they are insurable under P \& I. On the other hand, some are clearly related to workmen's compensation, which because of its peculiarities, will be treated separately later in this paper. It should be stressed that liability to third party vessels is substantially restricted under the provisions of the Canada Shipping Act. ${ }^{6}$

The risk of delay caused by strikes is sometimes insured under P \& I coverage. This is not really liability coverage and is more often insured by a "strikes club" operating out of Bermuda. The club is a mutual and is designed to protect mainly against delay caused by all manner of strikes. This is an area not usually considered by persons contracting drilling operations because western operators are used to hiring roughnecks who are more than willing to work for good wages. The only labour difficulty is keeping down the number of hours of overtime to avoid a fight with a Board of Industrial Relations. It becomes more complicated when the roughnecks are also longshoremen who may have to strike as a requirement of their union.

Another area in which P \& I insurance is used is that of war risk and confiscation. It must be remembered that marine drilling units have been used mostly in the waters of the South American countries and in the Middle East. The unstable political climates in these areas has resulted in insistence upon this type of coverage.

\section{Tower's Liability}

Contracts will also specify Tower's Liability with the "Sistership Clause" unamended. Tower's risks are normally excluded from Hull and P \& I policies. "Tug-form" is important, therefore, particularly when the drilling barge itself is being towed. It is a common failing of small contractors to lack coverage for Tower's Liability, so, as previously mentioned, it is important to review their policies.

\section{Excess Liability Insurance}

In addition to the Hull, $P$ \& I, and Tower's insurance, contracts call for Excess Liability insurance, or Umbrella insurance. This excess insurance is designed to fill any gaps which may not be covered under the other forms; or, at least to extend the amount of insurance monies available under the other forms. Excess limits will vary, but $\$ 10,000,000$ is probably average. It will have a deductible where primary insurance exists, or where it may be feasible to self-insure.

- R.S.C. 1970, c. S.9, PL. XIV, ss. 647(2) et seg. 
There is a tendency to become complacent when the operator acquires excess insurance. It should be stressed that the gaps it fills are in amounts. That is, there must be primary insurance. Excess insurance is only secondary. For that reason, it is necessary to closely examine exclusions in the primary coverage. Also, there must be an insurable interest, just as in primary insurance. The market for excess insurance is non-marine. That means that the wording will not be the same and there may be exclusions in the excess insurance.

\section{Clauses to Watch}

There are two or three clauses which may appear in marine policies and which should be briefly explained.

The "Sue and Labour" clause provides that in the case of a loss, the insured may "sue, labour, and travel" to ameliorate his loss. The insured is entitled to do so without prejudice to his claim for full indemnity under the contract, and is additionally insured for the expenses of his pursuit and labours; be they successful or not. Although the clause remains part of Lloyd's form, it may no longer be necessary because of the decision in Emperor Goldmining Co., Ltd. v. Switzerland General Insurance Co. Ltd., ${ }^{7}$ where the court held that, because it was the duty of the insured to minimize his loss, the insured should, under an "all risks" policy, be entitled to indemnity for his efforts, so long as the expenses were "properly" incurred. It should be stressed that the study to minimize the loss was statutory in this case, although the learned Justice did say that the statute was an embodiment of the common law. However, in Canada, the form of policy is defined by statute and the "Sue and Labour" clause is included, although it is discretionary. ${ }^{8}$

The "Waiver of Subrogation" clause is common. By such a clause, the insurer waives its rights of subrogation against any other party with whom the assured may be operating. The clause is usually made a requirement in the schedule of insurance in the drilling contract and is partly a follow-up to the indemnity provisions. Hand-in-hand with this "waiver" clause is the "Joint Venture" clause. As a result of the Torrey Canyon-type incidents, the underwriters have insisted upon an endorsement whereby, if the assured is a joint venturer or partner with others, the limit of the insurer's liability is the amount that the assured's interest in the joint venture or partnership bears to the amount of insurance payable under the policy. For example, if the assured holds a twenty-five percent interest in the joint venture, then the insurer's liability is limited to twenty-five percent of the amount stated as the limitation of liability in the policy. The partners would, of course, be named assureds in the policy. The reason for this provision is to avoid payment of one hundred percent of the face value of the policy as many times as there are partners (i.e. named assureds).

\section{INDEMNITY}

In order to understand the use of indemnity clauses, it is necessary to establish what the legal position would be without them. It will then be necessary to determine how that position may be altered in order to allocate responsibility in the manner negotiated between the parties.

; (1964) 1 Lloyd's Rep. 348 (S.C.N.S.W.).

s See e.g., Marine Insurance Act, R.S.B.C. 1960, c. 231; Marine Insurance Act, R.S.N.B. 1952, c. 238; Insurance Act, R.S.N.S. 1967, c. 148, Pt. IX. 
Primarily, the liability sought to be indemnified against is liability to third parties which may result from non-feasance, misfeasance, or malfeasance in performance of the contract.

At common law, the contractor has a contractual obligation to perform according to "good oilfield practice", i.e. "properly". If he fails to do so, he is liable for the consequences of his acts or omissions, irrespective of any negligence on his part. If the third party sues the operator, the operator obviously has a right of indemnity against the contractor. If there is an act of negligence, or if the third party frames his action in negligence, then the liability is not so clear cut. In the United States, there is a doctrine of active and passive negligence whereby the doer of the negligent act may be held to indemnify the party who had an interest but simply stood by and let the act proceed. In Canada, there is no acceptance of such a theory, although apportionment as between joint tortfeasors under findings of contributory negligence may come close to the same result. In many offshore accidents, the responsible party is not easily identified. Therefore, it is desirable to set forth in the contract the areas in which each party shall be responsible. Keeping that in mind, it is clear that many of the indemnity clauses now in use in offshore operating agreements are not very useful.

Indemnity clauses in offshore contracts are often entirely reciprocal. That is, the operator agrees to save harmless the contractor against all claims brought against the contractor and vice versa. The results are less than satisfactory. Such clauses tend to spawn litigation in order to determine responsibility. As mentioned earlier, underwriters refuse to insure pollution risks partly because of the problems of sorting out the indemnity agreements among the innumerable joint owners, contractors, and subcontractors involved in a drilling operation.

Several alternatives are available. By saying that each party shall be responsible for his own negligence is simply to state the common law position. By stating it in the contract, the courts are likely to assume that the parties in some way wished to change their responsibilities, and they may somehow make a determination based upon interpretation. Because of the uncertainty which results in this approach, it would be better to be silent than to put in such wording.

Some contracts stipulate that each party to the operation shall be responsible for his own employees and equipment notwithstanding that harm may come from another's negligence, the theory being that each can insure against his own risks and should not be concerned with the risks of others. The problem with this scheme is that it is essential to have the same agreement with each and every contractor on the project. Also, the drilling contractor would obviously bear a disproportionate share of the risk by having to insure his rig against the vagaries of various supply vessels.

The scheme which no doubt has the most appeal to the readers of this paper is that in which the oil company operator, because of its superior bargaining power, insists upon indemnity from all the contractors and subcontractors while giving nothing in return. Such an operator can be oblivious to the problem created thereby for the apportionment of responsibility among those contractors and subcontractors. It is to be hoped that the draughtsmen of indemnity clauses will appreciate the 
injustice of such documentation before the courts strike it down as unconscionable.

The preceding paragraph presently holds the key. The type of indemnity clause which results depends simply upon bargaining power. In the future, it may be that pressure from the underwriters coupled with a more active role by the courts will result in contractual percentage or dollar limits of indemnity. In that way indemnification will merely be a form of marine insurance: ${ }^{9}$

.... whereby the insurer [the contractor, or operator] undertakes to indemnify the assured, [the operator, or contractor] in manner and to the extent thereby agreed, against marine losses, that is to say, the losses incident to marine adventure.

\section{WORKMEN'S COMPENSATION}

Workmen's compensation has its own peculiar problems off Canadian shores. The employees are often American so they are not covered under workmen's compensation insurance by a home province. The operation may be in Canadian waters, but not necessarily in waters over which a province has jurisdiction. Although it is possible, in some instances, to negotiate workmen's compensation coverage with the nearest province there still remains the jurisdictional problem. Workmen's compensation insurance should provide that claims in rem be treated as claims against the employer, in personam.

There is also the Merchant Seaman Compensation Act, ${ }^{10}$ which has application only when the men are not covered by provincial compensation and are aboard Canadian vessels or vessels trading into Canada under Canadian charter. Its application is, at present, very limited for the offshore rig itself, but it may have applicability for some supply boats.

Offshore drilling really falls within the range of the Federal admiralty law and, as such, is subject to Federal labour requirements. The drilling contractor is an independent contractor in most instances, so the operator does not have a particular involvement except to be sure that employer liability insurance is obtained. The operator should be a named assured in the policies, however.

In the event a crew member is injured or dies as a result of drilling activities, then the insurer under the private policy will likely use local workmen's compensation scales for payments. In the event of a death, a capital fund may be paid to the Workmen's Compensation Board of a province to provide the payments for dependants under local statutes and regulations.

While it seems logical that the Federal Labour Code, the Canada Shipping Act, the Merchant Seaman Compensation Act, and the Workmen's Compensation legislation of the provinces should provide more than adequate coverage for employer's liability, it must be remembered that the employees may be American citizens. They may also be union men. This may bring them within certain American jurisdictions; either by implication, or as a matter of their employment contracts.

A United States Federal statute, commonly referred to as the "Jones Act", 11 provides that "any seaman" who suffers personal injury in the course of his employment may, at his election, maintain an action for

\footnotetext{
9 Marine Insurance Act, R.S.B.C. 1960, c. 231, s. 3.

10 S.C. 1970, c. M.11.

"I U.S. 41 Stat. 1007 8. 33.
} 
damages. It also authorizes an action for death benefits when death is a result of such injury.

The "Jones Act" was limited to "members of the crew" of vessels plying in navigable waters by The Longshoremen's and Harbor Workers' Compensation Act. ${ }^{12}$ There are now three requirements:

(1) The vessel must be in the course of navigation. Mobilization and demobilization of the drilling platform would presumably meet this requirement;

(2) The worker must have a more or less permanent connection with the ship. This was held to include a roughneck on a submersed barge in Gianfala v. Texas Co., ${ }^{13}$ although it is not a hard and fast rule;

(3) The worker should be primarily involved in navigation. "Navigation" has been widely construed to mean "interested in the operation and welfare of the ship in navigable waters".

Again, the Gianfala case seems wide enough to extend the "Jones Act's" applicability to practically any persons employed in offshore drilling. Its applicability to a drilling barge in Canadian waters may seem a little remote, but an operator may do well to see that his drilling contractor carries additional employer's liability insurance to cover the contingency.

\section{MISCELLANEOUS INSURANCE}

There are some miscellaneous insurances which should be obtained. They would appear, on the face of them, to be standard requirements or, at the very least, considerations in connection with any drilling venture-onshore or off.

Aircraft insurance will contain the usual provision, except that it must be adapted for helicopter landing on a swaying landing pad situated on an expensive drilling unit. Charterers should insist upon a minimum of $\$ 5,000,000$ worth of Public Liability and Property Damage insurance, and may expect to have to share in the increased premiums for that sort of coverage. The drilling contractor will likely stipulate the limits of coverage he will require from anyone setting a helicopter on his drilling unit.

As touched upon earlier, seepage and pollution insurance is virtually unobtainable beyond the limits of $\$ 1,000,000$. Comprehensive General Liability insurance (not to be confused with P \& I insurance, to which the operator is only a named insured under the contractor's policy) should be obtained. Ample limits, it is suggested, would be $\$ 15,000,000$ to $\$ 25,000,000$.

Many companies self-insure the cost of control of wild wells. They similarly self-insure down-hole equipment. The exposure is quite different for offshore wells, however. Wild well coverage unfortunately excludes the cost of bringing in a second rig if a relief well were necessary. The severe storms which occur off Canada's East Coast warrant the acquisition of additional coverage in both of these areas.

1233 U.S.C. ss. 901 et seq.

is (1955) 350 U.S. 879. 